\title{
Authentic Leadership and Teachers' Intention to Stay: The Mediating Role of Perceived Organizational Support and Psychological Capital
}

\author{
Andrea Aria ${ }^{1, *}$, Parivash Jafari ${ }^{2}$ \& Maryam Behifar ${ }^{3}$ \\ ${ }^{1}$ Computer Information Systems, Georgia State University, Atlanta, USA \\ ${ }^{2}$ Educational Administration, Islamic Azad University, Tehran, Iran \\ ${ }^{3}$ Technology Management, Islamic Azad University, Tehran, Iran \\ *Correspondence: Computer Information Systems, Georgia State University, Atlanta, USA. Tel: 1-404-702-6019. \\ E-mail: aaria@gsu.edu
}

Received: May 1, 2019

Accepted: June 18, 2019 Online Published: June 24, 2019

doi:10.5430/wje.v9n3p67

URL: https://doi.org/10.5430/wje.v9n3p67

\begin{abstract}
This paper aims to explore the mediation effect of psychological capital and perceived organizational support on the relationship between authentic leadership and intention to stay. The structural equation modeling technique was used to test the hypothesized model. A survey was administered to collect data targeting a sample of randomly selected teachers working at high schools in Tehran. The results suggest that authentic leadership significantly influences teachers' intention to stay, psychological capital, perceived organizational support. As predicted, both perceived organizational support and psychological capital had a significant positive direct effect on intention to stay. The effect of authentic leadership on intention to stay was found to be mediated by teachers' psychological capital and perceived organizational support. This study shows how leaders can enhance teachers' intention to stay by applying authentic leadership, engendering psychological capital and creating supportive environment.
\end{abstract}

Keywords: authentic leadership, psychological capital, perceived organizational support, teachers' intention to stay

\section{Introduction}

The most strategic resource of today's organizations is committed and motivated human resources. However, employees' turnover has imposed to organizations irreparable expenses and adverse outcomes. It seems that during the decision-making process to leave the job and choose a new alternative, emotional commitment and continuous commitment will decrease and the organization will face the reduction in the productivity of employees who do not intend to stay. The consequences of this issue are more obvious in educational organizations which have the mission of educating future generation and could not be neglected.

McKinsey's report on high-performing education systems suggests that one of the indicators of top education systems is the availability of qualitative teachers (McKinsey Report, 2007). So, recruiting and retention of quality teachers is one of the top priorities of managers in any education system. But global statistics show high rate of teachers' turnover (Arnup \& Bowles, 2016; Dassa \& Derose, 2017; Hong, 2010) for some reasons such as job stress, unfavorable working conditions (Kyriacou, 2001; Skaalvik \& Skaalvik, 2011; cited by Arnup \& Bowles, 2016), high workload, lack of school support and issues related to students' behavioral management (Kyriacou, 2001; cited by Arnup \& Bowles, 2016). Regarding the negative effects and consequences of quitting, one of the major concerns of managers and researchers is to find affecting factors of teachers intention to stay. According to proactive management, identifying determinants of teachers' intention to stay allow to take actions to retain them before they make decision about quitting organization.

The intention to stay in the job refers to the enthusiasm and intentional willingness of individuals to stay in the organization (Tett \& Meyer, 1993). The literature shows that various factors affect intention to stay. Most studies have examined the determinants of employee intention to leave and few studies have focused on teachers' intention to stay. While factors that lead to employee turnover do not necessarily encourage or enhance intention to stay (Cho, Johanson, \& Guchait, 2009). In addition, few studies have focused on teachers' intention to stay especially in Iran. 
This research gap has prepared a basis for this study to review some antecedents of teachers intention to stay in schools by focusing on positive psychology and positive variables (such as authentic leadership, perceived organizational support and psychological capital) instead of focusing on negative aspects (intention to quit, dissatisfaction, ...). So the main problem of this study is examining to what extent teachers' intention to stay is affected by authentic leadership, perceived organizational support and psychological capital? And if perceived organizational support and psychological capital mediate the relationship between authentic leadership and teachers intentions to stay? It is expected that identifying and understanding related factors of teachers' intention to stay would help policy-makers and planners to set policies and to develop and implement plans to prevent teachers' turnover and to reinforce valuable human capital retention.

\subsection{Authentic Leadership}

One of the variables which directly and indirectly related to intention to stay is leadership style and practice in organization (Haque, Fernando, \& Caputi, 2017, 2019; Kovner, Brewer, Fairchild, Poornima, Kim, \& Djukic, 2007; Laschinger, Wong, Grau \& PineauStam 2012; Oh 2017). But, it is important to identify the leadership style which enhances intention to stay. Today, managers have found that in today increasingly complex and changing world, it is not possible to cope with the serious challenge of retaining qualified and capable employees using traditional leadership styles. In his leadership handbook, Bryman (2011) has introduced authentic leadership as a solution to the challenges of leadership in current era. Avolio, Walumbwa \& Weber (2009) also considered authentic leadership as a key to solve ethical problems and create positive organizational climate.

The foundation of authentic leadership is authenticity. In the first effort to define leadership authenticity, Henderson (1983) pointed to employees' perception of the extent of coordination between speech and deed of leaders.

Authentic leadership is a model of leadership behavior that is based not only on positive psychological capacities and ethical climate, but also strengthens them (Walumbwa, Avolio, Gardner, Wernsing, \& Peterson, 2008). Luthans and Avolio (2003) defined authentic leadership as a process which draws from both positive psychological capacities of leader and a highly developed organizational context and results in self-awareness and self-regulated positive behaviors on the part of leader and followers, and fosters positive self-development. Luthans and Avolio (2003) determine the characteristics of an authentic leader as confident, hopeful, optimistic, resilient, ethical, futuristic, Prioritize the development of followers' leadership.

According to Walumbwa et al. model (2008), authentic leadership consists of four components: self-awareness, relational transparency, balanced processing and internalized moral perspective.

Self-awareness refers to leaders' awareness of their weakness and strength and their influences on situations and people (Walumbwa et al., 2008). Self-aware leaders are seeking self-development and continuous self-improvement through self-assessment (Glowacki-Dudka \& Treff, 2016).

Balanced processing refers to the unbiased processing of information and analysis of all relevant data objectively before making any decision. Leaders who benefit this behavior avoid over emphasizing on internal knowledge and externally generated information (Gardner, Avolio, Luthans, May, \& Walumbwa2005). Relational transparency means that leaders are real and honest in their communications and relationships with others (Kernis 2003, Northouse, 2013) and show their real self through open sharing of information about their thoughts, emotions and feelings (Walumbwa et al., 2008).Internalized moral perspective refers to the fact that leader is guided by internal ethical standards and uses it to self-regulate his behavior. A leader with these characteristics integrates his values and actions according to internal moral values (Walumbwa et al., 2008).

\subsection{Perceived Organizational Support}

This concept which was presented by Eisenberger, Huntington, Hutchison \& Sowa for the first time in 1986 refers to employees' general perception concerning the extent to which the organization values their contribution and cares about their well-being (Aselage \& Eisenberge, 2003; Eisenberge et al, 1986; Kurtessis, Eisenberger, Ford, Buffardi, Stewart, \& Adis, 2017; Rhoades, Eisenberger, \& Armeli, 2001). Organizational support uses social exchange theory (Blau, 1964) to better understand the relationships between employees and the organization (Casper, Harris, Taylor-Bianco, \& Wayne, 2011). According to the theory and norm of reciprocity (Gouldner, 1960), if employees perceive that the organization supports them, they feel obliged and committed to compensate for this support through arbitrary behaviors but in this exchange relationship, perception is usually beyond an economic exchange and includes social and emotional aspects such as care, respect and loyalty (Aselage \& Eisenberger, 2003). 


\subsection{Psychological Capital}

Luthans, Youssef-Morgan, \& Avolio. (2015, p. 2) define Psychological Capital as "a person's positive psychological state of development that is characterized by: (1) having confidence (efficacy) to take on and put in the necessary effort to succeed at challenging tasks; (2) making a positive attribution (optimism) about succeeding now and in the future; (3) persevering toward goals and when necessary, redirecting paths to goals (hope) in order to succeed; and (4) when beset by problems and adversity, sustaining and bouncing back and even beyond (resilience) to attain success."

Self-efficacy. It refers to one's belief and judgment about his/her ability to carry out a certain task (Bandura, 1977, 1997) and being succeed in accomplishing a certain task through self-motivation, supplying cognitive resources for himself/herself and also taking required actions (Luthans, Avolio, \& Youssef, 2007). Self-efficacy is rooted in Bandura's social cognitive theory (1977). This cognitive theory emphasizes on human agency, i.e. individual's ability to self-organizing and self-regulatory of emotions, acts and behaviors (Bandura, 1997, 2006). According to this theory, people are able directly both individually and collectively and through proxy agency to control environment and change environment conditions (Bandura, 2012; Hamil, 2003).

Hope. Hope is based on positive expectations or feelings about future outcomes and targets (Edwards, 2009). It refers to a positive motivational state which includes two components of agency (goal-directed energy) and pathway (planning to reach the goals) (Snyder, Irving, \& Anderson, 1991; Snyder, Rand, \& Sigmon, 2002).

Optimism. Optimism points to positive causal attributions and is a way in which individuals explain the causes of positive and negative events and expect positive result. Optimistic people rely on general attributions in facing their failures and successes; they attribute their successes to their own internal abilities and in facing failures attribute them to external certain unsustainable factors (Seligman \& Schulman, 1986).

Resilience. Resilience refers to the person's capacity for effective and successful coping and adaptation under adverse, difficult, unpleasant, threatening or challenging circumstances (Herrman, Stewart, Diaz-Granados, Berger, Jackson, \& Yuen 2011; Luthans, 2002; Masten, Best, \& Garmezy 1990), or even positive events and successes (Luthans, 2002). Highly resilient people have the ability to deal with stressful events through their personal capabilities and environmental resources (Bobek, 2002; cited in Arnup 2016; Cope, Jones, \& Hendricks, 2016).

\section{Theoretical Framework and Conceptual Model}

\subsection{Authentic Leadership and Intention to Stay}

Authentic leaders are characterized by a high level of authenticity, honesty in speech and integrity in behavior, high ethical standards and commitment to moral values in decision and action, caring about employee's development and well-being of employees (Avolio \& Gardner, 2005; Luthans, Youssef, et al., 2007), quality and transparency in communicating with followers, asking and accepting others' views and opinions (Walumbwa et al., 2008). By fostering a positive climate (Avolio \& Gardner, 2005; Blake et al., 2012; Gardner et al., 2005; Mrayyan, 2008; Nelson, Boudrias, Brunet, Morin, De Civita, Savoie, \& Alderson, 2014; Walumbwa et al., 2008; Woolley et al., 2010) authentic leaders engender trust in leader (Agote, Aramburu, \& Lines, 2016; Wang \& Hsieh, 2013; Wong \& Cumming, 2009). trust in leader, in turn, affects desirable performance outcomes such as satisfaction, retention, commitment, organizational citizenship behavior, and performance (Connell, Ferres, \& Travaglione, 2003; Corbitt \& Martz, 2003; Costa, 2003; Dirks \& Ferrin, 2002, cited in Norman, Avolio, \& Luthans, 2010) and reduces the intention to leave the job (Connell, Ferres, \& Travaglione, 2003; Dirks \& Ferrin, 2002) and improves the intention to stay in the job.

Empirical studies by Dirks and Ferrin, 2002, Munyaka, Boshoff, Pietersen, \& Snelgar, 2017, Laschinger, Wong, Cummings, and Grau, 2014, Norman et al. (2010) have shown that authentic leadershipas a positive leadership positively affects employees' satisfaction, commitment, and intention to stay and reduces employees' turnover intentions (Oh \& Oh, 2017). According to the above, the first hypothesis of this study could be as following:

H1: Authentic leadership has positive and significant effect on intention to stay.

\subsection{Authentic Leadership and Psychological Capital}

Leaders play a significant position in organization because of directing and supervising organization's affairs as well as influencing employees' attitudes and behaviors as role models (Lester, Vogelgesang, Hannah, \& Kimmey, 2010; Walker \& Henning, 2004). Hence any speech or deed by the leader acts as a massage to followers and will be the basis of their behavior and speech. By authentic leadership as one of the positive leadership styles and authentic leaders not only have psychological positive states but also focus on creating positive psychological capacities (Gardner et al., 2005; Luthans \& Avolio, 2003), So, one of the key outcomes of practicing authentic leadership 
would be development of employee's psychological capital (Luthans, Youssef, et al., 2007)

Through features such as internalized moral values, making decisions and acting based on high ethical standards, awareness of their weaknesses and strengths and understanding their effect on others (self-awareness), honestly and transparent dialogue with employees, positive emotions, confidence, hope, optimism and resilience (Luthans \& Avolio, 2003; Avolio, Gardner, Walumbwa, \& May, 2004), authentic leaders create positive relationship with employees (George, Sims, McLean, \& Mayer 2007) and increase job satisfaction of employees (Giallonardo, Wong, \& Iwasiw, 2010). This will probably lead to strengthen employees' psychological capital.

The followers of authentic leaders compared with other leadership styles followers experience more positive emotional states through emotional contagion from leader to them (Rego, Sousa, Marques, \& Cunha 2012). Several studies indicate that there is a positive and significant relationship between authentic leadership and psychological capital (Clapp-Smith, Vogelgesang, \& Avey, 2009; Feng-I, 2016; Jensen \& Luthans, 2006; Munyaka, et al., 2017; Peterson, Walumbwa, Avolio, \& Hannah, 2012; Rego et al., 2012; Walumbwa et al., 2011; Woolley, Caza, \& Levy, 2010). According to the above, the second hypothesis of this study could be as following:

H2: Authentic leadership has positive and significant effect on psychological capital.

\subsection{Authentic Leadership and Perceived Organizational Support}

Authentic leaders influence organizational climate (Walumbwa et al., 2008; Woolley et al., 2011) and their followers' well-being through numerous mechanisms (Ilies, Morgeson, \& Nahrgang, 2005). They foster a positive, ethical and safe climate through open and transparent communication, honesty, trust and genuine interest in their followers (Gardner et al., 2005), where followers can express themselves freely and respectfully (Macik-Frey et al., 2009; cited in Nelson et al., 2014) This affects positively employee's perception of the leader's support, and since they consider the leader as the representative of the organization, they extend this perception from leader to the organization. Therefore, the following hypothesis is proposed:

H3: Authentic leadership has positive and significant effect on perceived organizational support.

\subsection{Psychological Capital and Intention to Stay}

Avey, Luthans, \& Jensen (2009) described psychological capital as one's ability to face challenging situations, endurance against difficulties, and as well as patience and perseverance to achieve goals and achieve short and long term success. One of the reasons for decreasing employee intention to stay might be challenging and difficult situations in the job. According to the above definition of Psychology Capital, People with high psychological capital show patience and endurance in the face of hardship and this increases the likelihood of their intention to stay in the job.

As people makes decisions about carrying out a duty, extent of required efforts to do that and perseverance to accomplish it through their self-efficacy beliefs (Bandura, 1997), it is likely that by relying on their self-efficacy to control the environment and changing conditions (Bandura, 2012; Hamil, 2003) their intention to stay increases.

Studies show that people with high self-efficacy have a stronger belief in their ability to control thoughts, feelings, activities, and also effective performance in difficult and stressful situations (Caprara, Pastorelli, Regalia, Scabini, \& Bandura, 2005, Schunk, Pintrich, \& Meece, 2008), are more resilient in facing obstacles (Tschannen-Moran \& Gareis, 2004) and have more adaptability, higher organizational commitment and more job satisfaction (Caprara, Barbaranelli, Borgogni, \& Steca, 2003) which all will likely increase their intention to stay in the job.

On one side, whereas hopeful people have better consistency with different situation of their life through two factors of will power and finding the path power (Mathew, Dunning, Coats, \& Whelan, 2014) and could change their goals and demands (Feldman \& Kubota, 2015) They are likely to be more adaptable to their jobs and are more likely to stay in their jobs. High-hope people as compared with low-hope people are more decisive and confident in producing better and more diverse paths to achieve their goals, especially their career goals (Woodbury, 1999). This can increases likelihood of their intention to stay.

Optimism is the belief that good events will happen more than bad ones in the future (Scheier \& Carver, 2009). This attitude makes people different in dealing with problems and hardships. Given that they expect good events to happen in the future, they make more efforts in facing their problems. Consequently, they gain more success and less likely to leave their job. Studies have shown that optimism in organization is associated with performance, job satisfaction, and organizational commitment (Luthans et al., 2005; Youssef \& Luthans, 2007), higher productivity and less intention to turnover (Sligman \& Schulman, 1986) and more intention to stay (Pitterson \& Luthans, 2003). According to the above, the fourth hypothesis could be as follow: 
H4: Psychological capital has positive and significant effect on intention to stay.

\subsection{Perceived Organizational Support and Intention to Stay}

Eisenberger et al. $(1986,2002)$ explain perceived organizational support by using social exchange theory and mutual relationship and commitment between organization and employees. According to this mutual commitment, employees who feel that the organization supports them in difficult and stressful conditions (Rhoades \& Eisenberger, 2002), appreciates their efforts and contributions by tangible resources such as wage and payment, rank, job

enrichment, bonus or other fringe benefits and compensations, treat them fairly, and provide them with good working conditions (Eisenberger et al., 1986), display more positive feelings toward their organization, are more resilient to problems and challenges of the workplace and have more job satisfaction (Bakker \& Demerouti, 2007; Rhoades \& Eisenberger, 2002). This, in turn, can lead to an increase in the intention to stay in their jobs.

The findings of some studies also show when employees feel that leaders and employers value them, appreciate them and care about their well-being, their intention to quit will decrease (Alfes, Shantz, Truss, \& Soane, 2013; Boxall, Macky, \& Rasmussen, 2003; Perryer, Jordan, Firns, \& Travaglione, 2010) make more efforts to achieve organizational goals even in difficult and stressful situations and their intention to stay will increase (Rhoades \& Eisenberger, 2002; Johnston, 1995; Laschinger et al., 2012;), feel a sense of belonging in organization and are less likely to leave their job and search the new one (Arshadi, 2011; Eisenberger,et al., 2002; Loi et al., 2006; Maertz, Griffeth, Campbell, \& Allen, 2007; Rhoades \& Eisenberger, 2002; Kudo, Satoh, Hoso, iMiki, Watanabe, \& Kido, 2006) also showed that proper working conditions increase intention to stay. So, the following hypothesis is proposed:

H5: Perceived organizational support has positive and significant effect on intention to stay.

2.6 Mediating Role of Perceived Organizational Support and Psychological Capital in the Relationship between Authentic Leadership and Intention to Stay

When leaders treat employees favorably and care about them, the employees feel they are important and cared about them (Eisenberger et al., 1986, 2012). This matter makes them have more proper perception and insight about their organization and probably have more intention to stay in organization even in hard and improper situations.

Through shaping positive, transparent and honest relationships, paying close attention to employees' opinions and concerns, consistency between their words and deeds, and displaying high moral standards in decisions and actions (Walumbwa et al., 2008 ), authentic leaders create good and healthy work conditions for their followers. This would strengthen employees' belief that organization values them and their contribution by leaders as agents of organization (Levinson, 1965; cited in Eisenberger et al., 2002). This perception of support, in turn, makes people optimist and hopeful for the future, increases their resilience to hardships and difficulties, and strengthens belief in their ability to solve the problems. So, in the face of challenges, setbacks, and failures, there is more likely to stay in the job instead of quitting it.

Since the leadership focus is on influencing others and as the leader's behavior is contagious, authentic leadership as a positive leadership generate positive traits such as hope, optimism, resilience and self-efficacy among employees. These positive features, in turn, affect employees' attitudes, perceptions, and behaviors and thus increase their intent to stay.

Some studies also show that supportive behavior of the leader leads to increased commitment and loyalty of the employees to the leader (Chen, 2001), decreased intention to leave (Allen, Shore, \& Griffeth, 2003; Kalliath \& Beck, 2001; Laschinger et al., 2012) and increased intention to stay (Chen, 2001).

Studies also show authentic leadership through creating an ethical atmosphere and honest behavior with employees (Walumbwa et al., 2008), makes followers trust them (Bird, Wang, Watson, \& Murray, 2009; Eisenbeiss, 2012; Tschannen-Moran \& Hoy, 1998). Trust in the leader is associated with increasing job satisfaction and reducing intention to leave (Costigan, Insinga, Berman, Kranas, \& Kureshov, 2011; Gibson \& Petrosko, 2014; Tiplic, Brandmo, \& Elstad, 2015). So, the following hypothesis is proposed:

H6: Perceived organizational support and psychological capital mediate effect of authentic leadership on intention to stay 


\section{Methods}

\subsection{Measures}

The 16-item Authentic Leadership Questionnaire (ALQ) (Walumbwa et al. 2008) was used to measure teachers' perception of principal authentic leadership. The ALQ consists of four subscales: balanced processing (three items), moral/ethics (four items), relational transparency (five items), and self-awareness (four items). Sample item include: "My principal seeks feedback to improve interactions with others" (self-awareness). The coefficient alpha for the current study was 0.927 .

Perceived organizational support was measured using the short form version (16-item) of Perceived Organizational Support Scale (POS) (Eisenberger et al., 1986). Sample item include: "My organization really care about my opinion". The coefficient alpha for the current study was 0.940 .

Psychological Capital (PsyCap) was measured using the 24-item Psychological Capital Questionnaire (PsyCap Q) developed by Luthans, et al. (2007). The PsyCap Q includes four subscales: self-efficacy, hope, resilience, and optimism. Six items is used to measure each of the factors. Sample items are: "I feel confident in representing my work area in meetings with management" (self-efficacy), "If I should find myself in a jam at work, I could think of many ways to get out of it" (hope) "I can get through difficult times at work because I have experienced difficulty before" (resilience) and "I'm optimistic about what will happen to me in the future as it pertains to work" (optimism). The coefficient alpha for the current study was 0.947 .

Teachers' intent to stay was assessed using Price and Mueller's (1986) four-question scale. Cronbach's alpha for the Price and Mueller intent to stay measure have ranged from .85 to .90 (Kim, Price, Mueller, \& Watson, 1996; Price \& Kim, 1993). The coefficient alpha for the current study was 0.856 .

All measures were rated on a five-point Likert-type scale ranging from 1 (strongly disagree) to 5 (strongly agree). To estimate Content Validity Index (CVI), the questionnaires were given to 20 experts (with $\mathrm{PhD}$ degree in educational administration with at least ten-year' experience). Overall ratings for the 60 -item scale were judged to be relevant, and all of the CVI's were higher than .80. To review the necessity of each item, the Lawshe scale (CVR) was used. For all questions the CVR critical rate was greater than 0.5 .

\subsection{Participants}

It is generally accepted that the minimum sample size to ensure appropriate use of Maximum likelihood estimation (MLE) is 100. As we increase the sample size above this value, MLE increases its sensitivity to detect differences among the data. As the sample size becomes large (exceeding 400 to 500), the method becomes "too sensitive". A randomly selected sample consisted of 470 teachers working in high schools in Tehran completed the questionnaires. A total of 418 surveys were returned (return rate $=88.93 \%$ ). After excluding six invalid questionnaires due to the missing data or other errors, a total of 412 (217 male and 195 female) questionnaires were used for data analysis. The valid recovery rate was $87.65 \%$.

\section{Results}

Data were analyzed by SPSS 25 and AMOS 24. Calculated composite reliability (CR) for all construct ranged between 0.6 to 0.7 which indicates appropriate reliability. Moreover, skewness and kurtosis were tested for normality assumption. The values of average variance extracted (AVE) for each latent construct were measured and all of them were higher than the threshold of 0.5 (Hair, 2014). To test normality assumption, Shapiro-Wilk W. test has been used for each item separately, and Royston test has been used for multivariate normality assumption. Since P_Value was higher than 0.05 for all values, therefore, the assumption of the normalization of the data is not rejected.

\subsection{Measurement Model}

As the initial model had not the good fitness and should be adjusted. The Confirmatory Factor Analysis (CFA) was applied to determine the fitness of the modified model. Model fit indices of the modified measurement and structural model are showed in Table 1. 
Table 1. Fit Indices of the Modified Measurement and Structural Model

\begin{tabular}{lcc}
\hline \multicolumn{1}{c}{ Fit Indices } & Modified Measurement model & Structural model \\
\hline$\chi^{2} / \mathrm{df}$ & 2.83 & 1.92 \\
Goodness of Fit Index (GFI) & 0.828 & 0.801 \\
Adjusted GFI (AGFI) & 0.795 & 0.771 \\
Normed Fit Index (NFI) & 0.922 & 0.884 \\
Comparative Goodness of Fit & 0.943 & 0.941 \\
(CFI) & 0.943 & 0.941 \\
Incremental Fit Index (IFI) & 0.937 & 0.938 \\
Tucker Lewis Index (TLI) & 0.913 & 0.878 \\
Relative Fit Index (RFI) & 0.697 & 0.726 \\
Parsimony Adjusted GFI (PGFI) & 0.077 & 0.047 \\
Root Mean Square Error of & & \\
Approximation (RMSEA) & & .0 \\
\hline
\end{tabular}

The results show that the model reasonably fits the data. The ratio of $\chi^{2} / \mathrm{df}$ for the modified measurement and structural model is 2.83 and 1.92 respectively, which are lower than the recommended threshold of 3 by Carmines and McIver (1981). The value of GFI for modified measurement model is 0.828 and 0.801 for Structural model which are higher than or equal to 0.8 which indicating a good fit (Table 1). In the case of CFI, TLI, and IFI indices for both models, the values are higher than 0.90. According to Hu and Bentler (1999) the value of the RMSEA index is lower than 0.08 .

Also, all factor loadings values of variables were higher than 0.5 and they were significant at the $95 \%$ confidence level (Barki \& Hartwick, 2001).

\subsection{Structural Model (Testing Hypotheses)}

In structural model part, direct and indirect effects of variables were estimated. Table 2 shows the results of the analysis for the direct standard effects. Table 3 and Figure 1 represent the standardized direct, indirect and total effects.

Table 2. Structural Model: Direct Effects

\begin{tabular}{ccccccc}
\hline Hypothesis & & Path & & Path Coefficients & P Value & Conclusion \\
\hline $\mathrm{H}_{1}$ & Psc & $<---$ & Lid & $.572^{* * *}$ & 0.00 & Supported \\
$\mathrm{H}_{2}$ & POS & $<---$ & Lid & $.739^{* * *}$ & 0.00 & Supported \\
$\mathrm{H}_{3}$ & ITS & $<---$ & Psc & $.729^{* * *}$ & 0.00 & Supported \\
$\mathrm{H}_{4}$ & ITS & $<---$ & POS & $.158^{* *}$ & .012 & Supported \\
$\mathrm{H}_{5}$ & ITS & $<---$ & Lid & $.133^{*}$ & .089 & Supported \\
$\mathrm{H}_{6}$ & Psc & $<---$ & POS & $.468^{* *}$ & 0.00 & Supported \\
\hline
\end{tabular}

Note: $* * *$ significance at $\mathrm{p}<0.01, * *$ significance at $\mathrm{p}<0.05, *$ significance at $\mathrm{p}<0.1$

Based on Table 2 and Figure 1, Authentic leadership (Lid), Psychological Capital (Psc) and Perceived organizational support (POS) have a significant positive direct effect on Intention to stay (ITS). Similarly, authentic leadership (Lid) has a significant positive direct effect on Psychological Capital (Psc) and Perceived organizational support (POS), and Perceived organizational support (POS) affects Psychological Capital (Psc) positively. 


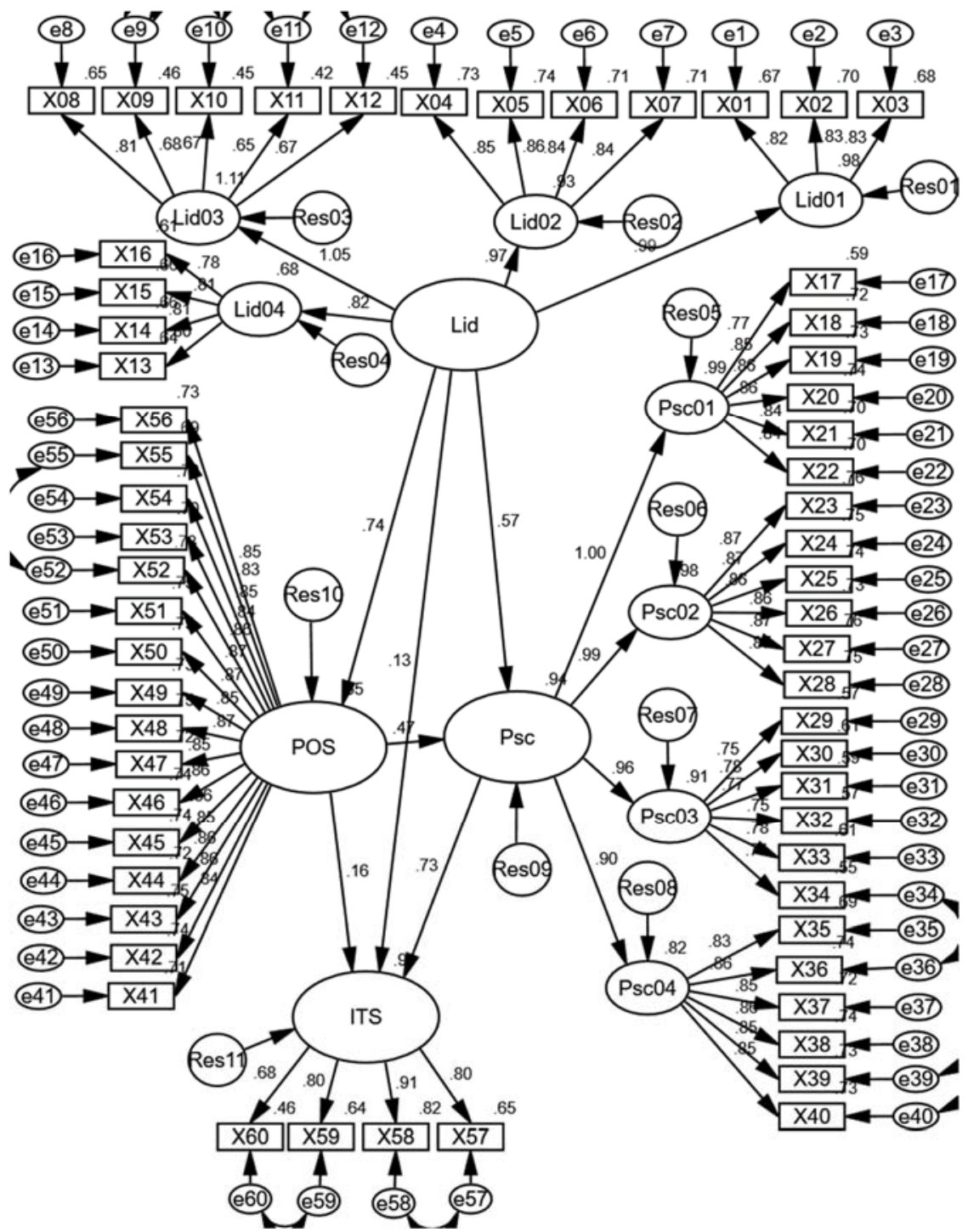

Figure 1. Structural Model SEM

In this model, the effect of psychological capital on intention to stay is only direct while authentic leadership and perceived organizational support have both direct and indirect effects on intention to stay.

Table 3. Direct, Indirect and Total Effects Results

\begin{tabular}{lccccccccc}
\hline & \multicolumn{3}{c}{ Standardized Direct Effects } & \multicolumn{5}{c}{ Standardized Indirect Effects } & \multicolumn{3}{c}{ Standardized Total Effects } \\
\hline & Lid & POS & Psc & Lid & POS & Psc & Lid & POS & Psc \\
POS & .739 & & & & & & .739 & & \\
Psc & .572 & .468 & & .346 & & & .918 & .468 & \\
ITS & .133 & .158 & .729 & .786 & .341 & & .919 & .499 & .729 \\
\hline
\end{tabular}

Table 3 shows the direct, indirect and total effects of statistically significant paths. Authentic leadership (Lid), Perceived organizational support (POS) and Psychological Capital (Psc) have direct effect on Intention to stay (ITS). The indirect effect of authentic leadership (Lid) on Intention to stay (ITS) through Psychological Capital (Psc) and Perceived organizational support (POS) is 0.786 . The indirect effect of authentic leadership (Lid) on Psychological Capital (Psc) is 0.346, and the indirect effect of Perceived organizational support (POS) on Intention to stay (ITS) is 0.341 . The total effect of authentic leadership (Lid) on Intention to stay (ITS) is 0.919 . Therefore, the mediation effect of psychological capital and perceived organizational support on the relationship between authentic leadership and intention to stay has been supported. 
$\mathrm{R}^{2}$ or the coefficient of multiple determinations for multiple regressions estimated for all paths. In general, $\mathrm{R}^{2}$ more than 0.3 indicates good explanatory power. Thus, the independent variables (authentic leadership, Psychological Capital and, Perceived organizational support) explain $98.8 \%$ of variance of Intention to stay $\left(\mathrm{R}^{2}=0.988\right)$. Further, authentic leadership and Perceived organizational support explain $94.2 \%$ of variance of Psychological Capital $\left(\mathrm{R}^{2}=\right.$ 0.942). Authentic leadership explains $54.7 \%$ of variance of Perceived organizational support $\left(\mathrm{R}^{2}=0.547\right)$.

\section{Conclusion and Discussion}

At present, the challenging and undesirable conditions of the teacher's job in many countries, including the Islamic Republic of Iran, have reduced the desire of teachers to stay in their job. As this study shows, Leaders play an important role in keeping the teachers' motivation engine running. The findings of this study showed authentic leadership directly and indirectly affects teachers' intention to stay in the job. This finding is consistent with the findings of Dirks and Ferrin (2002), Munyaka et al. (2017), Laschinger et al. (2014), Norman et al. (2010) and Oh \& Oh (2017) that authentic leadership relates positively to intention to stay and negatively to turnover intentions.

This study results suggest that educational leaders, using authentic leadership style, can increase teachers' intention to stay in the job through organizational support and psychological capital mechanisms. These findings suggest that the use of genuine leadership strengthens the psychological capital of employees, which in turn increases the intent of teachers to stay in the job. This finding is consistent with the findings of Rego et al. (2012) about contagion of positive emotions from leader to followers, as well as the role of the authentic leader in the development of positive emotions in employee (Walumbwa et al., 2008).

This finding is also aligned with the findings of Clapp-Smith, et al. (2009), Feng-I (2016), Jensen \& Luthans (2006), Munyaka et al. (2017), Peterson et al. (2012), Rego et al. (2012), Walumbwa et al. (2011), Woolley et al. (2010) who argue that authentic leadership influences employees' psychological capital, and support previous studies indicating that components of psychological capital are positively associated with intention to stay (Bandura 2012, Caprara et al., 2003, Peterson \& Luthans 2003), and negatively related to intention to quit (Seligman \& Schulman, 1986).

Through ethical decisions and actions and strengthening interpersonal relationship, authentic leaders enhance internal motivation, motivated people display more tolerance facing obstacles and challenges, are more hopeful about the future, insist to accomplish their duties and organizational goals, and may have more intention to stay.

By using authentic leadership style and establishing transparent relationship (Gardner et al., 2005; Walumbwa et al., 2011) with teachers, being open to different opinions, principals not only could improve motivation, create satisfaction, mutual understanding, trust (Agote et al., 2016; Bird et al., 2009; Eisenbeiss, 2012; Tschannen-Moran \& Hoy, 1998; Wang \& Hsieh, 2013; Wong \& Cumming, 2009) and loyalty (Chen, 2001), but also by seeking feedback, listening to complaints and trying to respond to them, make them believe that they are important for the organization. This leads to increase teachers' perceptions of organizational support. Furthermore, creating a sense of security and respect in them results in strengthening their morale. Based on the social exchange theory, once teachers perceive that the educational leaders (as the agents of organization) care about them, they will also compensate it by more commitment and better performance, and they will also be more likely to stay in their job

One of the applications of this study could be making positive changes in working environment through implementation authentic leadership and designing plans to help people stay in a teaching, and also changing policies to support teachers and meet their needs to strengthen their hope and optimism and exploiting this capital in reaching school's purposes. Considering the impact of authentic leadership on positive school environment (strengthening perceived support, Psychological Capital, and intention to stay) and as authentic leadership can be learned and developed (Avolio, Walumbwa, \& Weber, 2009), human resource managers could consider authenticity as an important criteria on principals 'recruitment, promotion training, and development programs.

Given to the effects of authentic leadership on teachers' intention to stay, it is recommended that the principals take due steps in continuous self-regulation and self-development toward internalizing values and features of authentic leadership through regular self-discovery and self-monitoring, identifying their weaknesses and strengths and applying 360 degree feedback, and show an internal commitment to externalize and exhibit these features in their leadership process. They can act as a role model through showing positive features in interaction with followers, change individual authenticity to collective one, and through creating a pleasant environment increase employee perceptions of organizational support and help them enhance their psychological capital, and ultimately increase their desire to stay in them.

In this study, teachers' intention to stay in the job, regardless of work experience, level of education, age, and gender 
has been investigated. Teachers' intention to stay in the job according to these variables may vary. Further studies are recommended considering the moderating role of these variables and comparing the results with this study results.

\section{References}

Adams, V. H., Snyder, C. R., Rand, K. L., King, E. A., Sigmon, D. R., \& Pulvers, K. M. (2002). Hope in the workplace. In R. Giacolone \& C. Jurkiewics (Eds.), Handbook of workplace spirituality and organizational performance (pp. 367-377). New York: Sharpe.

Agote, L., Aramburu, N., \& Lines, R. (2016). Authentic Leadership Perception, Trust in the Leader, and Followers Emotions in Organizational Change Processes. The Journal of Applied Behavioral Science, 52(1), 35-63, https://doi.org/10.1177/0021886315617531

Alfes, K., Shantz, A.D., Truss, C., \& Soane, E. C. (2013). The link between perceived human resource management practices, engagement and employee behavior: a moderated mediation model, The International Journal of Human Resource Management, 24, 330-351. https://doi.org/10.1080/09585192.2012.679950

Allen, D. G., Shore, L. M., \& Griffeth, R. W. (2003). The role of perceived organizational support and supportive human resource practices in the turnover process. Journal of Management, 29(1), 99-118. https://doi.org/10.1177/014920630302900107

Arnup, J., \& Bowles, T. (2016). Should I stay or should I go? Resilience as a protective factor for teachers' intention to leave the teaching profession. Australian Journal of Education, 60(3), 229-244. https://doi.org/10.1177/0004944116667620

Arshadi, N. (2011). The relationships of perceived organizational support (POS) with organizational commitment, in-role performance, and turnover intention: Mediating role of felt obligation. Procedia Social and Behavioral Sciences, 30, 1103-1108. https://doi.org/10.1016/j.sbspro.2011.10.215

Aselage, J., \& Eisenberger, R. (2003). Perceived Organizational Support and Psychological Contracts: A Theoretical Integration. Journal of Organizational Behavior, 24, 491-509. https://doi.org/10.2139/ssrn.2744707

Avey J. B., Avolio B. J., \& Luthans F. (2011). Experimentally analyzing the impact of leader positivity on follower positivity and performance. Leadership Quarterly, 21, 350-64. https://doi.org/10.1016/j.leaqua.2011.02.004

Avey, J. B., Luthans, F., \& Jensen, S. (2009). Psychological capital: A positive resource for combating stress and turnover. Human Resource Management, 48(5), 677-693. https://doi.org/10.1002/hrm.20294

Avey, J. B., Reichard, R. J., Luthans, F., \& Mhatre, K. H. (2011). Meta-analysis of the impact of positive psychological capital on employee attitudes, behaviors, and performance. Human Resource Development Quarterly, 22(2), 127-152. https://doi.org/10.1002/hrdq.20070

Avolio, B. J., Gardner, W. L., Walumbwa, F. O., Luthans, F., \& May, D. R. (2004). Unlocking the mask: A look at the process by which authentic leaders' impact follower attitudes and behaviors. The Leadership Quarterly, 15(6), 801-823. https://doi.org/10.1016/j.leaqua.2004.09.003

Bakker, A. B., \& Demerouti, E. (2007). The Job Demands-Resources model: state of the art. Journal of Managerial Psychology, 22(3), 309-328. https://doi.org/10.1108/02683940710733115

Bandura A., Caprara, G. V., Barbaranelli, C., Gerbino, M., \& Pastorelli, C. (2003). Role of affective self-regulatory efficacy in diverse spheres of psychosocial functioning. Child Development, 74(3), 769-82. https://doi.org/10.1111/1467-8624.00567

Bandura, A. (1977). Self-efficacy: Toward a unifying theory of behavioral change. Psychological Review, 84, 191-215. https://doi.org/10.1037/0033-295X.84.2.191

Bandura, A. (1997). Self-efficacy: The exercise of control. New York: Freeman.

Bandura, A. (2006). Adolescent development from an agentic perspective. In F. Pajares \& T. Urdan (Eds.), Self-efficacy beliefs of adolescents, (Vol. 5., pp. 1-43). Greenwich: Information Age.

Bandura, A. (2012). On the Functional Properties of Perceived Self-Efficacy Revisited. Journal of Management, 38(1), 9-44. https://doi.org/10.1177/0149206311410606

Bird, J., Wang, C., Watson, J. R., \& Murray, L. (2009). Relationships among principal authentic leadership and teacher trust and engagement levels. Journal of School Leadership, 19(2), 153-171. https://doi.org/10.1177/105268460901900202 
Blau, P. M. (1964). Exchange and power in social life. New York, NY: Wiley.

Blake, N., Blayney, F., Loera, T., Rowlett, C., \& Schmidt, D. (2012). A model of authentic leadership to support a healthy work environment. AACN Advanced Critical Care, 23(4), 358-361. https://doi.org/10.1097/NCI.0b013e31826b4d1b

Boxall, P., Macky, K., \& Rasmussen, E. (2003). Labor turnover and retention in New Zealand: The causes and consequences of leaving and staying with employers. Asia Pacific Journal of Human Resources, 41, 195-214. https://doi.org/10.1177/10384111030412006

Bryman, A. (ed.) (2011). The SAGE handbook of leadership. London, Los Angeles: SAGE.

Caprara, G. V., Barbaranelli, C., Borgogni, L., \& Steca, P. (2003). Efficacy beliefs as determinants of teachers' job satisfaction. Journal of Educational Psychology, 95, 821-832. https://doi.org/10.1037/0022-0663.95.4.821

Caprara, G. V., Pastorelli, C., Regalia, C., Scabini, E., \& Bandura, A. (2005). Impact of adolescents' filial self-efficacy on family functioning and satisfaction. Journal of Adolescent Research, 15, 71-97. https://doi.org/10.1111/j.1532-7795.2005.00087.x

Casper, W. J., Harris, C., Taylor-Bianco, A., \& Wayne, J. H. (2011). Work-family conflict, perceived supervisor support and organizational commitment among Brazilian professionals. Journal of Vocational Behavior, 79(3), 640-652. https://doi.org/10.1016/j.jvb.2011.04.011

Chen, Z. (2001). Further investigation of the outcomes of loyalty to supervisor: job satisfaction and intention to stay. Journal of Managerial Psychology, 16(7/8), 650-660. https://doi.org/10.1108/EUM0000000006305

Cho, S., Johanson, M. M., \& Guchait, P. (2009). Employees intent to leave: A comparison of determinants of intent to leave versus intent to stay. International Journal of Hospitality Management, 28, 374-381. https://doi.org/10.1016/j.ijhm.2008.10.007

Connell, J., Ferres, N., \& Travaglione, T. (2003). Engendering trust in manager-subordinate relationship. Personnel Review, 32(5), 569-587. https://doi.org/10.1108/00483480310488342

Costigan, R. D., Insinga, R. C., Berman, J. J., Kranas, G., \& Kureshov, V. A. (2011). Revisiting the relationship of supervisor trust and CEO trust to turnover intentions: A three-country comparative study. Journal of World Business, 46(1), 74-83. https://doi.org/10.1016/j.jwb.2010.05.019

Dassa, L., \& Derose, D. S. (2017). Get in the teacher zone: A perception study of pre-service teachers and their teacher identity. Issues in Teacher Education, 26(1), 110-113.

Edwards, L. M. (2009). Hope. In S. J. Lopez (Ed.).The encyclopedia of positive psychology (pp. 487-491). Oxford: Wiley-Blackwell.

Eisenbeiss, S. A. (2012). Re-thinking ethical leadership: An interdisciplinary integrative approach. The Leadership Quarterly, 23(5), 791-808. https://doi.org/10.1016/j.leaqua.2012.03.001

Eisenberger, R., Huntington, R., Hutchison, S., \& Sowa, D. (1986). Perceived Organizational Support. Journal of Applied Psychology, 71(3), 500-507. https://doi.org/10.1037/0021-9010.71.3.500

Feng-I, Feng. (2016). School Principals' Authentic Leadership and Teachers' Psychological Capital: Teachers' Perspectives. International Education Studies, 9(10), 245-255. https://doi.org/10.5539/ies.v9n10p245

Gardner, W. L., Avolio, B. J., Luthans, F., May, D. R., \& Walumbwa, F. (2005). Can you see the real me? A self-based model of authentic leader and follower development. The Leadership Quarterly, 16(3), 343-372. https://doi.org/10.1016/j.leaqua.2005.03.003

Gatling, A., Kang, H. J., A., \& Kim, J. S. (2016). The effects of authentic leadership and organizational commitment on turnover intention, Leadership \& Organization Development Journal, 37(2), 181-199. https://doi.org/10.1108/LODJ-05-2014-0090

George, B., Sims, P., McLean, A.N., \& Mayer, D. (2007). Discovering your authentic leadership. Harvard Business Review, 85(2), 129-157.

Giallonardo L. M., Wong, C. A., \& Iwasiw, C. L. (2010). Authentic leadership of preceptors: predictor of new graduate nurses' work engagement and job satisfaction, Journal of Nursing Management, 18(8), 993-1003. https://doi.org/10.1111/j.1365-2834.2010.01126.x

Glowacki-Dudka, M., \& Treff, M. (Eds.). (2016). Special Issue: Embodying authentic leadership through popular 
education at Highlander Research and Education Center. Adult Learning, 27(3), 95-97. https://doi.org/10.1177/1045159516651592

Gouldner, A. W. (1960). The Norm of Reciprocity A Preliminary Statement. American Sociological Review, 25, 161-178. https://doi.org/10.2307/2092623

Hamill, S. K. (2003). Resilience and self-efficacy: The importance of efficacy beliefs and coping mechanisms in resilient adolescents. Colgate University Journal of the Sciences, 35, 115-146.

Haque, A., Fernando, M., \& Caputi, P. (2017) The Relationship Between Responsible Leadership and Organizational Commitment and the Mediating Effect of Employee Turnover Intentions: An Empirical Study with Australian Employees. Journal of Business Ethics, 156(3), 759-774. https://doi.org/10.1007/s10551-017-3575-6

Haque, A., Fernando, M., \& Caputi, P. (2019) Responsible leadership, affective commitment and intention to quit: an individual level analysis. Leadership \& Organization Development Journal, 40(1), 45-64. https://doi.org/10.1108/LODJ-12-2017-0397

Henderson, J. E., \& Hoy, W. K. (1983). Leader authenticity: The development and test of an operational measure. Educational \& Psychological Research, 3(2).

Henderson, J. E., \& Brookhart, S. M. (1996). Leader Authenticity: Key to Organizational Climate, Health, and Perceived Leader Effectiveness. Paper presented at the Annual Meeting of the American Educational Research Association (New York, NY, April 8-12, 1996). Jackson, Brad, (editor.). https://doi.org/10.1177/107179199600300409

Hong, J. Y. (2010). Pre-service and beginning teachers' professional identity and its relation to dropping out of the profession. Teaching and Teacher Education, 26, 1530-1543. https://doi.org/10.1016/j.jbusres.2011.10.003

Herrman, H., Stewart, D. E., Diaz-Granados, N., Berger, E. L., Jackson, B., \& Yuen, T. (2011). What is resilience? Canadian Journal of Psychiatry, 56, 258-265. https://doi.org/10.1177/070674371105600504

Ilies, R., Morgeson, F. P., \& Nahrgang, J. D. (2005). Authentic leadership and eudae-monic well-being: Understanding leader-follower outcomes. The Leadership Quarterly, 16(3), 373-394. https://doi.org/10.1016/j.leaqua.2005.03.002

Jensen, S. M., \& Luthans, F. (2006). Relationship between entrepreneurs' psychological capital and their authentic leadership. Journal of Managerial Issues, 18(2), 254-273.

Kalliath, T. J., \& Beck, A. (2001). Is the path to burnout and turnover paved by a lack of supervisory support? A structural equations test. New Zealand Journal of Psychology, 30(2), 72-78.

Kernis, M. H. (2003). Toward a conceptualization of optimal self-esteem, Psychological Inquiry, 14(1), 1-26. https://doi.org/10.1207/S15327965PLI1401_01

Kim, S., Price, J., Mueller, C., \& Watson, T. (1996). The determinants of career intent among physicians at a U.S. Air Force hospital. Human Relations, 49(7), 947-976. https://doi.org/10.1177/001872679604900704

Kovner, C. T., Brewer, C. S., Fairchild, S., Poornima, S., Kim, H., \& Djukic, M. (2007). Newly licensed RNs' characteristics, work attitudes, and intentions to work. The American Journal of Nursing, 107(9), 58-70. https://doi.org/10.1097/01.NAJ.0000287512.31006.66

Kudo, Y., Satoh, T., Hosoi, K., Miki, T., Watanabe, M., Kido, S. et al. (2006). Association between intention to stay on the job and job satisfaction among Japanese nurses in small and medium-sized private hospitals. Journal of Occupational Health, 48, 504-513. https://doi.org/10.1539/joh.48.504

Kurtessis, J. N., Eisenberger, R., Ford, M. T., Buffardi, L. C., Stewart, K. A., \& Adis, C. S. (2017). Perceived organizational support: A meta-analytic evaluation of organizational support theory. Journal of Management, 43(6), 1854-1884. https://doi.org/10.1177/0149206315575554

Laschinger, H. K. S., Wong, C. A., \& Grau, A. L. (2012). The influence of authentic leadership on newly graduated nurses' experiences of workplace bullying, burnout and retention outcomes: A cross-sectional study. International Journal of Nursing Studies, 49(10), 1266-1276. https://doi.org/10.1016/j.jinurstu.2012.05.012

Laschinger, S. H. K., Wong, C. A. M., Grau, A. L., Read, E. A., \& PineauStam, L. M. (2012). The influence of leadership practices and empowerment on Canadian nurse manager outcomes. Journal of nurse management, 20(7), 877-88. https://doi.org/10.1111/j.1365-2834.2011.01307.x 
Lester, P. B., Vogelgesang, G., Hannah, S. T., \& Kimmey, T. (2010). Developing courage in followers: Theoretical and applied perspectives. In C. Pury \& S. Lopez (Eds.), The psychology of courage: Modern research on an ancient virtue (pp. 210-245). Washington, DC: American Psychological Association. https://doi.org/10.1037/12168-010

Luthans F., Youssef-Morgan C. M., \& Avolio, B. (2015). Psychological Capital and Beyond. New York: Oxford Univesity Press.

Luthans, F., \& Avolio, B. J. (2003). Authentic leadership development. In K.S, Cameron, J.E. Dutton, \& R.E. Quinn (Eds.), Positive organizational scholarship (pp. 241-258). San Francisco, CA: Berrett-Koehler.

Luthans, F., Youssef, C. M., \& Avolio, J. B. (2007). Psychological capital: Developing the human competitive edge. New York: Oxford University Press.

Maertz Jr, C. P., Griffeth, R. W., Campbell, N. S., \& Allen, D. G. (2007). The effects of perceived organizational support and perceived supervisor support on employee turnover. Journal of Organizational Behavior, 28, 1059-1075. https://doi.org/10.1002/job.472

Masten, A. S., Best, K. M., \& Garmezy, N. (1990). Resilience and development: Contributions from the study of children who overcome adversity. Development and Psychopathology, 2, 425-444. https://doi.org/10.1017/S0954579400005812

Mathew J., Dunning C., Coats C. H., \& Whelan T. H. (2014). The mediating influence of hope on multi dimensional perfectionism and depression. Personality and Individual Differences, 70, 66-71. https://doi.org/10.1016/j.paid.2014.06.008

McKinsey Report (2007). How the World's Best-Performing School Systems Come out on Top. Retrieved from http://alamin99.wordpress.com/2008/02/22/mckinsey-report/

Mrayyan, M. T. (2008). Hospital organizational climates and nurses' intent to stay: Differences between units and wards. Contemporary Nurse, 27(2), 223-236. https://doi.org/10.5172/conu.2008.27.2.223

Munyaka, S. A., Boshoff, A. B., Pietersen, J., \& Snelgar, R. (2017).The relationships between authentic leadership, psychological capital, psychological climate, team commitment and intention to quit. SA Journal of Industrial Psychology, 43, a1430. https://doi.org/10.4102/sajip.v43i0.1430

Nelson K, Boudrias J. S., Brunet L., Morin D., De Civita M., Savoie A., \& Alderson M. (2014). Authentic leadership and psychological well-being at work of nurses: the mediating role of work climate at the individual level of analysis. Burnout Research, 1(2), 90-101. https://doi.org/10.1016/j.burn.2014.08.001

Norman; S. M., Avolio B. J., \& Luthans, F. (2010). The impact of positivity and transparency on trust in leaders and their perceived effectiveness. The Leadership Quarterly, 21(3), 350-364. https://doi.org/10.1016/j.leaqua.2010.03.002:

Northouse, P. G. (2013). Leadership: Theory and Practice. Los Angeles: Sage.

Oh, J., \& Oh, S. (2017). Authentic leadership and turnover intention: does organizational size matter? Leadership \& Organization Development Journal, 38(7), 912-926. https://doi.org/10.1108/LODJ-08-2016-0209

Perryer, C., Jordan, C., Firns, I., \& Travaglione, A. (2010). Predicting turnover intentions. The interactive effects of organizational commitment and perceived organizational support. Management Research Review, 33, 911-923. https://doi.org/10.1108/01409171011070323

Peterson, S. J., \& Luthans, F. (2003). The Positive Impact and Development of Hopeful Leaders. Leadership and Organizational Development, 24(1), 26-31. https://doi.org/10.1108/01437730310457302

Peterson, S., Walumbwa, F. O., Avolio, B. J., \& Hannah, S. T. (2012). The relationship between authentic leadership and follower job performance: The mediating role of follower positivity in extreme contexts. Leadership Quarterly, 23(3), 502-516. https://doi.org/10.1016/j.leaqua.2011.12.004

Price, J., \& Kim, S. (1993). The relationship between demographic variables and intent to stay in the military: Medical personnel in a U.S. Air Force hospital. Armed Forces and Society, 20(1), 125-144. https://doi.org/10.1177/0095327X9302000108

Price, J., \& Mueller, C. (1986). Handbook of organizational measurement. Marshfield, MA: Pitman.

Rego, A., Sousa, F., Marques, S., \& Cunha, M. P. C. (2012). Authentic leadership promoting employees' 
psychological capital and creativity. Journal of Business Research, 65(3), 429-437. https://doi.org/10.1016/j.jbusres.2011.10.003

Rhoades, L., \& Eisenberger, R. (2002). Perceived organizational support: A review of the literature. Journal of Applied Psychology, 87(4), 698-714. https://doi.org/10.1037/0021-9010.87.4.698

Rhoades, L., Eisenberger, R., \& Armeli, S. (2001). Affective commitment to the organization: The contribution of perceived organizational support. Journal of Applied Psychology, 86(5), 825-836. https://doi.org/10.1037/0021-9010.86.5.825

Schunk, D. H., Pintrich, P. R., \& Meece, J. L. (2008). Motivation in education: Theory, research, and applications (3rd ed.). Upper Saddle River, NJ: Pearson Education, Inc.

Seligman, M. E. P., \& Schulman, P. (1986). Explanatory style as a predictor of productivity and quitting among life insurance sales agents. Journal of Personality and Social Psychology, 50, 832-838. https://doi.org/10.1037/0022-3514.50.4.832

Singh, A. P., \& Amish. (2015). Role of Trustworthy Behavior in Turnover intention Among Front Level Managerial Personnel. Journal of the Indian Academy of Applied Psychology, 41(3), 95-103.

Smith, B. D. (2005). Job retention in child welfare: effects of perceived organizational support, supervisor support and intrinsic job value. Children and Youth Service Review, 27, 153-169. https://doi.org/10.1016/j.childyouth.2004.08.013

Snyder, C. R., Irving, L., \& Anderson, J. R. (1991). Hope and health: Measuring the will and the ways. In C. R. Snyder, \& D. R. Forsyth (Eds.), Handbook of social and clinical psychology: The health perspective (pp. 285-305). Elmsford, NY: Pergamon Press

Snyder, C. R., Rand, K. L., \& Sigmon, D. R. (2002). Hope theory. In C. R. Snyder \& S. Lopez (Eds.), Handbook of positive psychology (pp. 257-276). Oxford, UK: Oxford University Press.

Tett, R. P., \& Meyer, J. P. (1993). Job satisfaction, organizational commitment, turnover intention, and turnover: Path analyses based on meta-analytic findings. Personnel psychology, 46(2), 259-293. https://doi.org/10.1111/j.1744-6570.1993.tb00874.x

Tiplic, D., C. Brandmo \& E. Elstad. (2015). Antecedents of Norwegian Beginning Teachers' Turnover Intentions. Cambridge Journal of Education, 45(4), 451-474. https://doi.org/10.1080/0305764X.2014.987642

Tschannen-Moran, M., \& Hoy, W. K. (1998). Trust in schools: A conceptual and empirical analysis. Journal of Educational Administration, 36(4), 334-352. https://doi.org/10.1108/09578239810211518

Tschannen-Moran, M., \& Gareis, C. R. (2004). Principals' sense of efficacy: Assessing a promising construct. Journal of Educational Administration, 4(5), 573-585. https://doi.org/10.1108/09578230410554070

Walker, L. J., \& Henning, K. H. (2004).Differing conceptions of moral exemplarity: Just, brave, and caring. Journal of Personality and Social Psychology, 86(4), 629-647. https://doi.org/10.1037/0022-3514.86.4.629

Walumbwa, F. O., Avolio, B. J., Gardner, W. L., Wernsing, T. S., \& Peterson, S. J. (2008). Authentic Leadership: Development and Validation of a Theory-Based Measure. Journal of Management, 34, 89-126. https://doi.org/10.1177/0149206307308913

Wang, D., \& Hsieh, C. (2013). The effect of authentic leadership on employee trust and employee engagement. Social Behavior and Personality: An International Journal, 41(4), 613-624. https://doi.org/10.2224/sbp.2013.41.4.613

Wayne, S., Shore, L., \& Liden, R. (1997). Perceived organizational support and leader- member exchange: A social exchange perspective. Academy of Management Journal, 40(1), 82-111. https://doi.org/10.2307/257021

Wong, C. A., \& Laschinger, H. K. S. (2013). Authentic leadership, performance, and job satisfaction: the mediating role of empowerment. Journal of Advanced Nursing, 69(4), 947-959. https://doi.org/10.1111/j.1365-2648.2012.06089.x

Wong, C. A., \& Cummings, G. G. (2009). The influence of authentic leadership behaviors on trust and work outcomes of health care staff. Journal of Leadership Studies, 3(2), 6-23. https://doi.org/10.1002/j1s.20104

Woodbury, C. A. (1999). The relationship of anxiety, locus of control and hope to career indecision of African American students. Dissertation Abstracts International: Section A. Humanities and Social Sciences, 59(11-A), 4072. 
Woolley, L., Caza, A., \& Levy, L. (2010). Authentic leadership and follower development: psychological capital, positive work climate, and gender. Journal of Leadership \& Organizational Studies, 18(4), 438-448. https://doi.org/10.1177/1548051810382013

Youssef, C., \& Luthans, F. (2007). Positive organizational behavior in the workplace: the impact of hope, optimism, and resilience. Journal of Management, 33(5), 774-800. https://doi.org/10.1177/0149206307305562 